\title{
Developing a Collection for Chinese Studies
}

By S. K. LI

EVER SINCE the fall of the Chinese mainland to the Communists in 1949, the subject of China has been a highly controversial issue not only in United States politics but also in the United Nations. With the drastic change of China and its significant impact on the world, the demand for publications from China and about China has considerably increased in the last decade. The establishment of more research centers on Communism and the call for teaching about Communism in secondary education are other developments which require even a school library to develop a certain collection on China. College and research libraries are now, more than ever before, in need of better collections for the study of China.

In the face of the United States' nonrecognition policy toward the Chinese Communists and especially of the prohibition of "trade with the enemy" as enacted during the Korean war, acquisition librarians have encountered considerable difficulties in ordering publications originated on the Chinese mainland. On March 17, 1961, the restriction on Chinese books was slightly relaxed, when President Kennedy ordered the end of an interception system under which the Customs Bureau had withheld or destroyed Communist propaganda sent to the United States from behind the Iron Curtain. This administrative order, however, has caused a heated debate in Congress as well as among organizations and individuals regarding the distinction between "Red propaganda" and material of research value and questioning whether or not the post office should forward materials for the Communists. To promote research on the develop-
Mr. Li has been Reference Librarian of the Chinese News Service in New York for the past ten years.

ments of the Chinese mainland, the Treasury department now issues import documents for books and magazines originating in Red China, while all other Chinese imports are still forbidden.

It goes without saying that nearly all materials from the Chinese mainland are Communist literature or non-Communist classical works annotated by the Communists. A typical example of the Chinese Communist approach to the traditional Chinese culture is their interpretation of Confucianism. At the forum of the China Society of Philosophy recently held in Peiping, the participants heatedly debated whether Confucius was a "reactionary," when he said: "Don't do to people what you do not wish to be done to yourself." Like their perversion of modern world history that it was the Soviet Union rather than the United States that had been the main force in defeating the Japanese militarists in World War II, is Peiping's historians' characterization of the long history of China as a history full of struggles between poor exploited peasants and the feudal landlords.

Even in scientific literature, Peiping's theoreticians, believing that the rules of dialectical materialism are the only universal law of all social and natural phenomena, attempt to apply dialectics to scientific knowledge, regardless of making any sense of the subject. Chinese theories of medicine read "like an allegory from the time of Charlemagne heavily loaded with Marxist dialectics," says Dr. W. W. Bauer, director emeritus 
of health education, American Health Association. ${ }^{1}$ Quoting an article by Arthur F. Gonzalez which appeared in a recent issue of Today's Health (published by the American Medical Association), Dr. Bauer noted: "[Chinese] patients are supposed to fight their sickness with strong will power and revolutionary optimism."2

Chinese Communism is indeed more doctrinaire than Russian Communism. Pyotr Kapitsa, one of the Soviet Union's outstanding scientists, openly conceded in a recent issue of the Ekonomiches Kaya Gazeta, economic newspaper of the Soviet Communist Party, that dialectics alone could not solve any scientific problem, and he attempts to apply this thesis as the unique clue to what has hampered the progress of the Soviet science. ${ }^{3}$ On August 1 the Soviet Communist Party unprecedently announced that the party would not intervene in a theoretical dispute in the field of medicine.

While the Chinese Communists are rapidly transforming the pattern of the Chinese way of life to suit their totalitarian ideology, Taiwan is now a reservoir of traditional Chinese culture. To strengthen its research program on China, Stanford University established last fall a Chinese culture-research institute in Taiwan headed by Albert Dien, a sinologist. In addition to books from Taiwan and the Chinese mainland, publications about China from United States publishers and the university press have been voluminous in recent years. Librarians, collecting materials for research on China, should be able to draw from all the three major sources: Taiwan, Chinese mainland, and United States publishers and research centers.

British and French publishers also turn out quite a number of books on China. However, a British bibliography on China entitled Modern China com-

1 Seattle Times, December 13, 1961.

${ }^{2}$ New York Mirror, June 6, 1962. piled by Richard Harris lists more publications of American and Chinese publishers than those published in the United Kingdom. The China Quarterly published in London by the Information Bulletin, Ltd. on behalf of the Congress for Cultural Freedom is a scholarly journal which carries not only research articles on China but also a quarterly chronicle and documentation.

Inside the Communist bloc, production of books about China is rather limited in content, largely due to lack of freedom of speech. For instance, Premier Khrushchev criticized the Chinese commune system a number of times in speeches. Yet no one in the Soviet Union has written a book critically examining Mao Tse-tung's commune adventures. In 1946 the Harvard University Press published a bibliography of Russian literature on China and adjacent countries. Compiled by Rudolf Lowenthal, the bibliography covers the period from 1931 to 1936. Tung-li Yuan's Russian Works on China in American Libraries, covering the period, 1918-1960, was published by the Yale University Press in 1961. The following is a separate and brief review of the publications from the Chinese Mainland, Taiwan, and the United States.

\section{Mainland China}

Strictly speaking all publications from mainland China now are but Chinese Communist "government" publications, because under the severest communization program in the world no private publisher in China can do business without official approval and substantial support from the Communist machinery. Since the Communist occupation of the mainland in 1949 up to the end of 1950 , the sole Chinese government publishing enterprise was the Hsin Hua (New China) book company with some three thousand branch offices all over the country. In accordance with resolutions adopted by a national conference of the company 
in the fall of 1950, the business of the company was split into three independent units: the Hsin Hua Book Company, using the original title of the company, as the sole national distributor of all publications in the nation; the Hsin Hua printing plant as the unit of production; and the People's Publishing House as the government publisher.

Since 1951, even the nominally private companies such as the Commercial Press, the Chung Hua Book Company and the Kai Ming Book Company have gradually handed over their circulation business to the national distributor Hsin Hua to "reduce handling expenses and to avoid competition in the same business." Starting January 1, 1953, the Ministry of Posts and Tele-Communications took over the management of circulation of newspapers and periodicals in accordance with new measures governing the improvement of publication circulation work promulgated on December 30, 1952, while the Hsin Hua Book Company with a number of other book stores continued handling the sales of irregular series and general books including textbooks and pictorials.

Aside from the People's Publishing House as the government publisher of general political, economic, and cultural works, the Bureau of Publication Affairs of the Ministry of Culture has set up separate publishing agencies to turn out books on special subjects such as the People's Science and Technology Press, the People's Medical Science Press, the China Youth Press, and the People's Literature Press. Meanwhile the nominally private publishers in Red China have been respectively assigned to emphasize certain subjects. The Commercial Press and the Chung Hua Book Company are to turn out more publications on science, engineering, and agriculture, the Kai Ming Book Company is to stress applied science, history, literature, and "middlelevel" reading materials, and the $\mathrm{Ta}$
Tung Book Company is to emphasize children's literature.

According to 1960 Chinese Communist statistics, there are 119 publishers on the Chinese mainland who turned out in the year a total of $2,393,090,000$ volumes under 46,018 titles; 1,884 newspapers, and 808 periodicals. Among Peiping's major national dailies are the Jen Min Jih Pao ("People's Daily"), organ of the Central Committee of the Chinese Communist Party, the Kung Jen Jih Pao ("Daily Worker"), organ of the National Federation of Labor Unions, the Kuang Ming Jih Pao ("The Illuminating Daily"), organ of the satellite political parties in China or the voice of the fellow-travelling Chinese intellectuals on the mainland, the Ta Kung Pao ("The Impartial"), nominally owned by civilians and officially assigned to publish stories on problems of commerce, finance, and economics, and the Wen Huei Pao, also nominally a civilian paper, assigned to publish materials for teachers in the public schools.

The major Chinese Communist national magazines include the Hongq $i$ ("Red Flag"), fortnightly theoretical journal of the Chinese Communist Party; the Scientia Sinica ("China's Science") published monthly by the Chinese academy of science; the fortnightly Chung Huo Ching Nien ("Chinese Youth"), organ of the Chinese Communist youth corps; the monthly Hsueh $\mathrm{Hsi}$ ("Studies"), designed for general indoctrination of the Communist cadres and the masses; the monthly Jen Min Wen Hsueh ("The People's Literature"), organ of the Union of Chinese Writers; and the Chung-kuo Fu-nu ("Chinese Women"), fortnightly organ of the All China Women's Federation.

For foreign consumption, the Chinese Communists publish such periodicals as the Peking Review in English, a "weekly magazine of news and views;" the fortnightly China Pictorial, available in sixteen foreign languages including Eng- 
lish; the monthly China Reconstructs in English and Spanish; and the monthly Chinese Literature in English, mainly translations of contemporary and classical Chinese literature. The Foreign Language Press in Peiping is the principal publisher on the Chinese mainland that produces books and periodicals in Western languages. The Quozi Shudien (International Book Store) is the sole distributor for the Foreign Language Press publications.

For the reference of research workers and policy makers, the American Consulate-General in Hong Kong releases a daily Survey of China Mainland Press, a monthly Selections from Mainland Magazines, and Current Background, a collection of articles on a certain subject. All three releases are English translations of texts of articles which had appeared in the Chinese Communist periodicals or daily newspapers. Also in Hong Kong, the China News Analysis, a comprehensive and analytical English weekly news digest of the China mainland press, is useful in helping the people outside the curtain to catch up with the current development on the Chinese mainland. The University of Hong Kong has published a reference tool entitled Contemporary China. Edited by Stuart Kirby, the 1958 edition contains research papers on the current issues of the Chinese Communist movements, the most important documents of the Reds, and a bibliography of books and periodical articles about China published in the British colony and in Taiwan.

\section{TAIWAN}

To keep the public informed about the new books published in Taiwan, the bibliography center of the National Central library in Taipei compiles and publishes a Monthly List of Chinese Books. In addition to the continual listing of a "monthly list of Chinese publications" the journal carries scholarly articles, abstracts, and a selected list of Chinese publications arranged by the Dewey decimal system. The most useful reference book about Taiwan and the major developments on the Chinese mainland is the China Yearbook published in English by the China Publishing Company in Taipei. Following the inauguration of the Republic of China in 1911, this annual has continued publication up to the present time. Illustrated with charts, maps, and photographs, the yearbook contains comprehensive data on Chinese politics, economic development, and cultural activities.

Another annual useful for the study of Taiwan is the Taiwan Directory published by the China News and Publications Service in Taipei. The directory lists basic information on Chinese $\mathrm{Na}$ tionalist government organizations, American diplomatic and military missions, Chinese and American firms, and interesting tourist data. Most of the Taiwan radio stations and newspapers are also listed in the directory. Among the more than thirty dailies published in Taiwan, the Central Daily News reflects the Chinese Nationalist official views on the current issues. The two English dailies published in Taipei are the China News and the China Post.

Of the more than five hundred periodicals published in Taiwan, those in English include the China Culture Quarterly, the monthly Free China Review, the monthly China Today, the Free China and Asia monthly, and the monthly Industry of Free China. Among the Chinese periodicals the best known in the purely literary field are the monthly Wen-hsueh Tsa-chih ("Literary Magazine") and the monthly Wen Hsing ("Literary Star"). The Information Department of the Taiwan provincial government published a 136-page booklet comprising a complete list of the periodicals, newspapers, news agencies, publishers, and radio stations now in Taiwan.

While the monthly Free China Review 
is rich in resource material on current subjects, the quarterly Chinese Culture is the scholarly journal which turns out not only academic works but also bibliographical data and reference materials useful for research on Chinese traditions. In cooperation with the China Cultural Foundation, the Institute of Chinese Culture, publisher of the quarterly journal, has published a three-hundred-volume China Study Series. The series carries such useful bibliographies as an index of articles in learned periodicals of China published since 1912, by Chang Chun; index to educational articles, 1946-56, by Szu Chi; bibliography of Chinese bibliographies from ancient to modern times, by Liang Tze-han; and the national bibliography of the Republic of China by the National Central library. For foreign readers, the National Central library publishes a selected bibliography of the Republic of China. Arranged by subjects, this selected list of books is published together with a directory of publishers in Taiwan. Section VII of the bibliography lists the most important works on Chinese history and ancient classics.

The Ssu-ku Shan-pen Ts'ung-shu Kuan, Chinese rare-book publisher in Taipei, has started reproducing in facsimile a series entitled Ssu-ku Shan-pen Ts'ung-shu ("Collected Reprints of Rare Works from the Four Classics of Chinese Literature"). The Taipei China News reported early in 1962 that the World Book Company in Taipei would publish before the end of the year 1,000 of the original 11,095 volumes of the Yung-loh Ta-tien ("Yung-loh Encyclopedia"), reputed to be the greatest academic endeavor in Chinese history. Compiled by some three thousand scholars during over four years in the early fifteenth century by the order of Emperor Cheng Tsu of the Ming dynasty on the basis of all the books available at that time, the four-hundred-million-word set covers the entire range of human knowl- edge in China up to that period. The emperor named it Yung-loh Ta-tien after his reigning title Yung Loh. The Yungloh Ta-tien, completely a hand-copy work, is now incomplete because of destruction during social disturbances in Chinese history and in 1900 in the wake of the disastrous Boxer Rebellion.

\section{UNITED STATES WORKS}

While the Yung-loh Ta-tien is concerned with works up to the fifteenth century, Henri Cordier's Bibliotheca Sinica, with its final volume printed in 1924, recorded publications in western languages from sixteenth century up to the twentieth century. To continue Cordier's Bibliotheca Sinica, Tung-li Yuan completed in 1958 his China in Western Literature. This bibliography includes all publications produced both inside and outside China in the western languages from 1921 to 1957. In 1961, Yuan's Guide to Doctoral Dissertations by Chinese Students in America, 1905 1960, was released under the auspices of the Sino-American Society. To provide information on books released on the Chinese mainland, the East Asian Research Center of Harvard University has compiled a bibliography entitled Chinese Communist Studies of Modern Chinese History listing some five hundred books dating up to 1959 .

According to Edwin Beal of the Library of Congress, the first of the three volumes of an index to the Chinese collectanea was published in Communist China in 1959.4 Comparatively up-todate information on the development of the various fields on the Chinese mainland was made available by the United States Joint Publications and Research Services by releasing among other things a bibliography, Contemporary China, in 1961. It lists titles and a brief description of the contents of the articles which appeared in the Chinese mainland serials

\footnotetext{
4ibrary of Congress Quarterly Journal of Current
} Acquisitions, February 1961, 66-67. 
from late 1957 to July 1960. All articles listed have been translated from Chinese into English. Prepared for the joint committee on contemporary China of the American Council of Learned Societies and the Social Science Research Council, the bibliography was compiled under the coordination of the technical service of the Department of Commerce.

Meanwhile, G. K. Hall \& Co. announced in August the publication of an Index to Learned Chinese Periodicals of the East Asian Library of Columbia University. The index is an author and subject guide to the contents of thirteen Chinese journals, covering the years 1923 to 1954. In addition to the East Asian Institute of Columbia University, other major institutions or libraries doing research and holding large collections on China include the Library of Congress, Chinese Division; the University of California (Berkeley), Center for Chinese Studies; the University of Chicago, Far Eastern library; Harvard University, East Asian Research Center and ChineseJapanese library; University of Michigan, Department of Foreign Studies; Stanford University, Hoover Institution on War, Revolution and Peace; University of Washington, Far Eastern and Russian Institute; and Institute of Far Eastern Studies, Seton Hall University. The American Institutions and Organizations Interested in Asia compiled by Asia Society is a comparatively complete list of
United States organizations concerned with Chinese studies.

The Journal of Asian Studies, organ of the Association for Asian Studies, Inc., is essential to research on China. Its comparatively comprehensive book reviews together with an annual bibliography will keep one up-to-date about publications in the field. Other publications of the association, the newsletter and the monographs, are also helpful. With the expansion of United States research programs on China, the study of the Chinese language has steadily increased not only at the research centers but also in secondary education. According to a survey recently conducted by the Institute of Far Eastern Studies, Seton Hall University, there are now twenty high schools, four adult education programs and seventeen elementary schools in the United States where instruction of the Chinese language is given in one way or another. ${ }^{5}$

Universities which offer comprehensive Chinese language courses include Princeton, Columbia, Southern California, Stanford, Yale, American, Georgetown, Michigan State, Michigan, Minnesota, St. Louis, Cornell, Oregon, Pennsylvania, Pittsburgh, Washington, Wisconsin, and Ohio State.

5 "Report on the Teaching of the Chinese Language in High Schools," by Dr. John B. Tsu at the annual meeting of the Association of Teachers of Chinese Lang. uage and Culture held on May 11, 1962, at the Univer. sity of Maryland, College Park.

\section{Midwest Academic Librarians Conference}

ST. Louis UNIVERSITY and Washington University are jointly sponsoring the eighth Midwest Academic Librarians conference on April 5 and 6 in St. Louis. Registration and Friday's meetings will be at Washington University; Saturday morning's and lunch will be at St. Louis University. Speakers will include Joseph H. Reason, executive secretary of ACRL, Eugene Mackey of the architectural firm of Murphy and Mackey, St. Louis, who designed the Washington University Library building. Don Oehlerts, Colorado State University, and Baniel P. Bergen, St. Benedict's College, will lead round table discussions. 